\title{
GAMBARAN DETERMINAN PERILAKU MASYARAKAT DALAM PEMANFAATAN JASA TUKANG GIGI PADA PEMBUATAN GIGI TIRUAN LEPASAN DI DESA TREMAN KECAMATAN KAUDITAN
}

\author{
${ }^{1}$ Thirsa O. Lumunon \\ ${ }^{2}$ Vonny N. S. Wowor \\ ${ }^{2}$ Joenda S. Soewantoro
${ }^{1}$ Kandidat Skripsi Program Studi Pendidikan Dokter Gigi Fakultas Kedokteran Universitas Sam Ratulangi Manado Manado
Email: Thirsalumunon@gmail.com \\ ${ }^{2}$ Program Studi Pendidikan Dokter Gigi Fakultas Kedokteran Universitas Sam Ratulangi
}

\begin{abstract}
The loss of teeth can be caused by various diseases such as caries and periodontal diseases. This tooth loss can lead to disruption of the speech function, mastication, and aesthetics. Dentures for replacing the missing teeth are important to avoid such impacts. This study aimed to describe the determinants of people's behavior in the utilization of dental services of the removable denture makers in Treman village, Kauditan. This was a descriptive study. Taro Yamane formula was used to determine the number of samples. The method of sampling was purposive sampling by using questionnaires to 52 people. The results showed that the primary external factor determinant in the community toward the service of removable denture makers was the economic factor (the cost of maintenance) with a score of 250, meanwhile the internal factor determinant was perception with a score of 173 . Conclusion: The most important determinant related to the service of the removable denture makers was the external factor, which was the cost of maintenance. It is suggested that the government provides more affordable oral health care by adding health personnels, especially the dentists .
\end{abstract}

Keywords: determinants, people's behavior, removable denture makers, removable denture

\begin{abstract}
Abstrak: Kehilangan gigi dapat disebabkan oleh berbagai penyakit seperti karies dan penyakit periodontal yang dapat berakibat terganggunya fungsi bicara, pengunyahan, dan estetika. Pembuatan gigi tiruan untuk menggantikan gigi yang hilang penting dilakukan agar dapat menghindari akibat tersebut. Penelitian ini bertujuan untuk mengetahui gambaran determinan perilaku masyarakat dalam pemanfaatan jasa tukang gigi pada pembuatan gigi tiruan lepasan di desa Treman kecamatan Kauditan. Penelitian ini merupakan penelitian deskriptif. Pengambilan sampel menggunakan rumus Taro Yamane, dan metode pengambilan sampel dilakukan secara purposive sampling dengan membagikan kuesioner pada sampel yang berjumlah 52 orang. Hasil penelitian ini menunjukkan bahwa determinan penentu utama faktor eksternal masyarakat dalam pemanfaatan jasa tukang gigi untuk pembuatan gigi tiruan lepasan ialah faktor ekonomi dengan skor penilaian 250, dalam hal ini biaya perawatan. Determinan penentu faktor internal ialah faktor pengamatan, dengan skor penilaian 173. Simpulan: Determinan penentu utama masyarakat desa Treman, Kauditan, dalam pemanfaatan jasa tukang gigi untuk pembuatan gigi tiruan lepasan ialah faktor eksternal dalam hal ini faktor ekonomi yang menyangkut biaya perawatan. Disarankan pada pemerintah agar dapat menyediakan pelayanan kesehatan gigi dan mulut yang lebih terjangkau oleh masyarakat dengan menambah tenaga kesehatan, khususnya dokter gigi.
\end{abstract}

Kata kunci: determinan, perilaku masyarakat, tukang gigi, gigi tiruan lepasan

Kehilangan gigi merupakan ukuran umum kesehatan mulut yang buruk karena berdampak pada pengunyuhan, berbicara dan fungsi sosial. Kejadian hilangnya gigi dapat disebabkan oleh beberapa hal, antara lain: trauma, karies, penyakit 
periodontal.Apabila gigi yang hilang tidak segera diganti dengan gigi tiruan, maka akan timbul berbagai akibat, antara lain: bergesernya gigi asli ke ruang bekas gigi yang hilang, erupsi berlebih, penurunan efisiensi kunyah.

Berdasarkan data WHO tahun 2012 tentang kesehatan mulut menunjukkan bahwa $30 \%$ populasi di dunia pada usia 65-74 tahun telah mengalami kehilangan seluruh gigi, sedangkan target WHO tahun 2010 untuk kasus kehilangan gigi hanya sebesar 5\%. ${ }^{3}$ Hasil Riset Kesehatan Dasar (RISKESDAS) Departemen Kesehatan Republik Indonesia tahun 2007 menggambarkan bahwa sebesar $1,8 \%$ kasus kehilangan gigi ditemukan pada kelompok umur 45-54 tahun,5,9\% pada kelompok umur 55-64 tahun dan 17,6\% pada kelompok umur 65 tahun ke atas. ${ }^{4}$

Kasus kehilangan gigi yang masih cukup banyak menggambarkan besarnya kebutuhan akan perawatan Prostodonsia. Perawatan Prostodonsia dalam hal ini diperlukan untuk memperbaiki serta mempertahankan fungsi gigi melalui pembuatan gigi tiruan sebagai pengganti gigi asli yang telah hilang dan digunakan untuk mengembalikan fungsi fonetik, mastikasi dan estetik. Didalam bidang kedokteran gigi, gigi tiruan terbagi atas, Gigi tiruan lepasan dan Gigi tiruan cekat. ${ }^{2}$

Pembuatan gigitiruan merupakan salah satu jenis pelayanan kesehatan yang

\section{METODE PENELITIAN}

Jenis penelitian ini ialah penelitian deskriptif dengan pendekatan crosssectional. Jumlah sampel yang diteliti yaitu 52 orang, berdasarkan rumus Taro Yamane dan sampel diambil menggunakan metode purposive sampling.

Determinan perilaku masyarakat dalam pemanfaatan jasa tukang gigi pada pembuatan gigi tiruan di desa Treman kecamatan Kauditan, diukur menggunakan 13 pertanyaan yang terdiri dari 5 faktor eksternal dan 8 pertanyaan faktor internal. Kemudian diberikan skor untuk 1-5: tidak

dilakukan oleh dokter gigi, namun kenyataan yang ada di lapangan menunjukkan bahwa banyak masyarakat yang melakukan perawatan pembuatan gigi tiruan di tukang gigi. Banyak faktor yang melatarbelakangi seseorang dalam penggunaan jasa tukang gigi untuk pembuatan gigitiruan. Faktor-faktor tersebut antara lain: faktor perilaku masyarakat, faktor ekonomi, faktor pelayanan kesehatan. Beberapa faktor dimaksud antara lain faktor biaya, ketersediaan sarana pelayanan, ketersediaan tenaga kesehatan yang kompeten dalam pembuatan gigi tiruan.,

Data tukang gigi penelitian Pada survei awal yang dilakukan penulis ditemukan data jumlah dokter gigi yang terdaftar di Dinas Kesehatan Minahasa Utara sebanyak 4 orang $^{7}$, sedangkan jumlah penduduk Minahasa Utara yang harus dilayani tercatat sebanyak 188.467 jiwa. Kondisi ini masih jauh dari ideal bila dibandingkan dengan ratio ideal dokter gigi dengan masyarakat yakni 1: 10.000.

Desa Treman merupakan salah satu desa yang berada di Kecamatan Kauditan Kabupaten Minahasa Utara. Data awal yang diperoleh menunjukkan 9 dari 10 masyarakat desa Treman ternyata membuat gigi tiruan dengan menggunakan jasa tukang gigi dengan alasan murah dan tempatnya mudah dijangkau.

setuju $=1$; kurang setuju $=2$; setuju $=3$; sangat setuju $=4$; amat sangat setuju $=5$. Data hasil pengukuran secara kontinum dapat dilihat seperti:

$\overbrace{\begin{array}{l}\text { Kurang menentukan } \\ \text { menentukan }\end{array}}^{52} \begin{aligned} & 121,33 \\ & \text { menentukan }\end{aligned}$




\section{HASIL PENELITIAN}

Desa Treman merupakan salah satu desa yang berada di Kecamatan Kauditan Kabupaten Minahasa Utara. Desa ini memiliki luas sebesar 1.447 ha. Sebelah Utara berbatasan dengan gunung Klabat, sebelah Timur berbatasan dengan desa Kawiley kecamatan Kauditan dan desa Lango kecamatan Kema, sebelah Selatan berbatasan dengan desa Lilang kecamatan Kema, dan sebelah Barat berbatasan dengan Kaima kecamatan Kauditan. Desa Treman memiliki jumlah penduduk 3439 jiwa dengan jumlah laki-laki sebanyak 1692 jiwa dan perempuan sebanyak 1724 jiwa.

Karakteristik responden penelitian

Responden dalam penelitian ini yaitu masyarakat desa Treman kecamatan Kauditan yang berusia 25 tahun sampai dengan 82 tahun, menggunakan gigi tiruan lepasan yang dibuat oleh tukang gigi. Jumlah responden yang diteliti sesuai dengan besar sampel yang telah ditentukan, yaitu berjumlah 52 orang. Karekteristik responden dilihat berdasarkan jenis kelamin, usia, tingkat pendidikan dan status pekerjaan.

Distribusi frekuensi responden penelitian berdasarakan jenis kelamin yang telah dikelompokan dapat dilihat pada Tabel 1.

Tabel 1. Distribusi frekuensi responden berdasarkan jenis kelamin

\begin{tabular}{ccc}
\hline Jenis kelamin & $\mathrm{N}$ & $\%$ \\
\hline Laki-laki & 20 & 38,46 \\
Perempuan & 32 & 61,34 \\
\hline Total & 52 & 100 \\
\hline
\end{tabular}

Data pada tabel 1 menunjukkan bahwa dari 52 responden yang diteliti terdapat 20 orang $(38,46 \%)$ berjenis kelamin laki-laki dan 32 orang $(61,34 \%)$ berjenis kelamin perempuan.

Distribusi tingkat pendidikan responden yang berbeda dapat dilihat pada Tabel 2 .
Gambaran umum desa Treman kecamatan Kauditan

Tabel 2. Distribusi frekuensi responden berdasarkan tingkat pendidikan

\begin{tabular}{ccc}
\hline $\begin{array}{c}\text { Tingkat } \\
\text { pendidikan }\end{array}$ & $\mathrm{N}$ & $\%$ \\
\hline SD & 10 & 19,23 \\
SMP & 7 & 13,46 \\
SMA & 31 & 59,62 \\
Perguruan & 4 & 7,71 \\
tinggi (PT) & & \\
Tidak sekolah & 0 & 0 \\
\hline Total & 52 & 100 \\
\hline
\end{tabular}

Data pada tabel 2 menunjukkan bahwa responden dengan tingkat pendidikan SD berjumlah 10 orang $(19,23 \%)$, SMP berjumlah 6 orang $(13,46 \%)$, SMA berjumlah 31 orang (59,62\%), PT 4 orang $(7,71 \%)$ dan responden yang tidak sekolah dalam penelitian ini tidak ada.

Distribusi frekuensi responden berdasarkan pekerjaan dapat dilihat pada tabel 3 di bawah ini:

Tabel 3. Distribusi frekuensi responden penelitian berdasarkan pekerjaan

\begin{tabular}{ccc}
\hline Pekerjaan & N & $\%$ \\
\hline Bekerja & 19 & 36,54 \\
Tidak bekerja & 33 & 63,46 \\
\hline Total & 52 & 100 \\
\hline
\end{tabular}

Data tabel 3 menunjukkan bahwa pekerjaan dari responden penelitian yaitu, yang bekerja berjumlah 19 orang (36,54\%) dan tidak bekerja 33 orang $(63,46 \%)$.

Gambaran determinan perilaku masyarakat pengguna gigi tiruan lepasan yang dibuat oleh tukang gigi di desa Treman kecamatan Kauditan.

Untuk mendapatkan gambaran determinan yang melatarbelakangi masyarakat pengguna gigi tiruan lepasan yang dibuat oleh tukang gigi di desa Treman kecamatan Kauditan, alat ukurnya menggunakan kuesioner yang terbagi 
dalam 13 belas pertanyaan yang berisi penilaian tentang determinan perilaku masyarakat pengguna gigi tiruan lepasan yang dibuat oleh tukang gigi. Hasil penelitian dapat dilihat pada Tabel 4 hingga Tabel 10.

Tabel 4.Distribusi penilaian factor pelayanan kesehatan sebagai faktor determinan eksternal perilaku masyarakat dalam pemanfaatan jasa tukang gigi

\begin{tabular}{|c|c|c|c|c|c|c|c|}
\hline \multirow{2}{*}{$\begin{array}{l}\mathrm{N} \\
\mathrm{O}\end{array}$} & \multirow{2}{*}{$\begin{array}{l}\text { Pelayanan } \\
\text { Kesehatan }\end{array}$} & \multicolumn{5}{|c|}{ Alternatif Penilaian } & \multirow[t]{2}{*}{ Skor } \\
\hline & & TS & $\begin{array}{l}\text { K } \\
\text { S }\end{array}$ & S & SS & $\begin{array}{l}\text { A } \\
\text { S } \\
\text { S }\end{array}$ & \\
\hline 1. & $\begin{array}{l}\text { Sarana } \\
\text { pelayanan } \\
\text { (puskemas,ruma } \\
\text { h sakit, praktek } \\
\text { pribadi dokter } \\
\text { gigi) tersedia }\end{array}$ & 11 & 0 & 0 & 164 & 0 & 175 \\
\hline 2. & $\begin{array}{l}\text { Sarana } \\
\text { pelayanan } \\
\text { (puskesmas, } \\
\text { rumah } \\
\text { sakit,praktek } \\
\text { pribadi dokter } \\
\text { gigi) letaknya } \\
\text { jauh/ sulit } \\
\text { dijangkau }\end{array}$ & 13 & 0 & 18 & 132 & 0 & 163 \\
\hline 3 & $\begin{array}{l}\text { Sarana } \\
\text { pelayanan } \\
\text { kesehatan yang } \\
\text { ada tidak } \\
\text { melayani } \\
\text { pembuatan gigi } \\
\text { tiruan }\end{array}$ & 11 & 0 & 111 & 4 & 0 & 126 \\
\hline \multirow[t]{3}{*}{4} & $\begin{array}{l}\text { Tidak ada } \\
\text { tenaga dokter } \\
\text { gigi di sarana } \\
\text { pelayanan } \\
\text { kesehatan yang } \\
\text { ada }\end{array}$ & 0 & 0 & 15 & 16 & $\begin{array}{c}21 \\
5\end{array}$ & 246 \\
\hline & & & & & & $\begin{array}{l}\mathrm{T} \\
\text { ot } \\
\text { al }\end{array}$ & 722 \\
\hline & & & & & & $\begin{array}{l}\text { sk } \\
\text { or }\end{array}$ & 180 \\
\hline
\end{tabular}

Berdasarkan skala di atas, dapat dilihat bahwa skor penilaian rata-rata faktor pelayanan kesehatan sebagai faktor determinan eksternal perilaku masyarakat tergolong dalam kategori menentukan.
Distribusi penilaian faktor ekonomi sebagai faktor determinan eksternal perilaku masyarakat dalam pemanfaatan jasa tukang gigi dapat dilihat pada Tabel 5 berikut ini:

Tabel 5. Distribusi penilaian faktor ekonomi sebagai faktor determinan eksternal perilaku masyarakat dalam pemanfaatan jasa tukang gigi

\begin{tabular}{|c|c|c|c|c|c|c|}
\hline \multirow[t]{2}{*}{ Ekonomi } & \multicolumn{5}{|c|}{ Alternatif penilaian } & \multirow[t]{2}{*}{ Skol } \\
\hline & TS & KS & S & SS & ASS & \\
\hline \multirow[t]{3}{*}{$\begin{array}{l}\text { 1. Pembuatan gigi } \\
\text { tiruan pada } \\
\text { tukang gigi } \\
\text { lebih } \\
\text { terjangkau dari } \\
\text { segi ekonomi }\end{array}$} & 0 & 0 & 9 & 16 & 225 & 250 \\
\hline & & & & & Total & 250 \\
\hline & & & & & $\begin{array}{l}\text { Skor } \\
\text { rata-rata }\end{array}$ & 250 \\
\hline
\end{tabular}

Berdasarkan skala di atas dapat dilihat bahwa skor penilaian rata-rata faktor ekonomi sebagai faktor determinan eksternal perilaku masyarakat berada pada kategori sangat menentukan.

Penilaian faktor determinan eksternal perilaku masyarakat yang paling menentukan dalam pemanfaatan jasa tukang gigi distribusinya dapat dilihat pada Tabel 6 di bawah ini:

Tabel 6. Distribusi penilaian faktor determinan eksternal perilaku masyarakat yang paling menentukan dalam pemanfaatan jasa tukang gigi

No Faktor determinan $\quad$ Skor

\begin{tabular}{llll}
\hline 1. & Pelayanan kesehatan & & 180 \\
\hline 2. & Ekonomi & & 250 \\
\hline & & Total & 430 \\
\hline & & $\begin{array}{l}\text { Skor rata- } \\
\text { rata }\end{array}$ & 215 \\
\hline
\end{tabular}


Secara keseluruhan memberikan gambaran faktor eksternal dengan skor penilaian rata-rata 215, tergolong kategori sangat menentukan.

Distribusi penilaian faktor pengamatan sebagai faktor determinan internal perilaku masyarakat dalam pemanfaatan jasa tukang gigi dapat dilihat pada Tabel 7 .

\begin{tabular}{|c|c|c|c|c|c|c|c|}
\hline \multirow{3}{*}{$\begin{array}{cc}\text { Tabel } & \\
& \\
\mathrm{N} & \mathrm{P} \\
\mathrm{O} & \end{array}$} & \multicolumn{2}{|c|}{$\begin{array}{l}\text { 7. Distribusi } \\
\text { pengamatan } \\
\text { determinan } \\
\text { masyarakat }\end{array}$} & \multicolumn{3}{|c|}{$\begin{array}{c}\text { penilaian } \\
\text { sebagai } \\
\text { internal }\end{array}$} & \multicolumn{2}{|c|}{$\begin{array}{r}\text { faktor } \\
\text { faktor } \\
\text { perilaku }\end{array}$} \\
\hline & \multirow[t]{2}{*}{ Pengamatan } & \multicolumn{5}{|c|}{ Alternatif Penilaian } & \multirow[t]{2}{*}{ Skor } \\
\hline & & $\begin{array}{l}\mathrm{T} \\
\mathrm{S}\end{array}$ & KS & $\mathrm{S}$ & SS & ASS & \\
\hline 1. & $\begin{array}{l}\text { Pembuatan } \\
\text { gigi tiruan } \\
\text { pada tukang } \\
\text { gigi lebih } \\
\text { murah } \\
\text { dibandingka } \\
\text { n pada } \\
\text { dokter gigi } \\
\text { atau sarana } \\
\text { pelayanan } \\
\text { kesehatan } \\
\text { lainnya. }\end{array}$ & & 10 & 66 & 28 & 90 & 194 \\
\hline
\end{tabular}

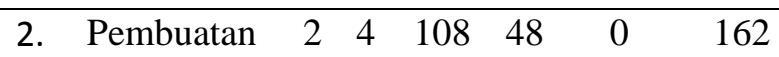
gigi tiruan

di tukang

gigi lebih

cepat.

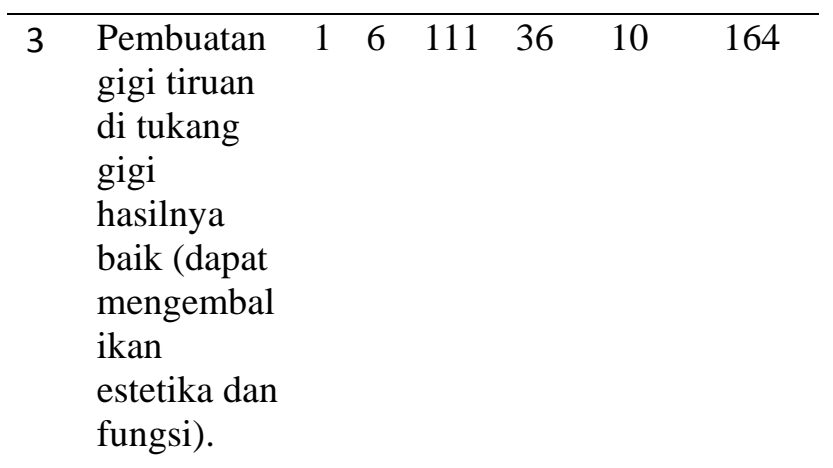

\begin{tabular}{lll}
\hline & Total & 520 \\
\hline & Skor & 173 \\
rata2 & 173 \\
\hline
\end{tabular}

Berdasarkan skala di atas dapat dilihat bahwa skor penilaian rata-rata faktor ekonomi sebagai faktor determinan eksternal perilaku masyarakat berada pada kategori sangat menentukan.

Distribusi penilaian faktor persepsi sebagai faktor determinan internal perilaku masyarakat dalam pemanfaatan jasa tukang gigi dapat dilihat pada Tabel 8 .

Tabel 8.Distribusi penilaian faktor persepsi sebagai faktor determinan internal perilaku masyarakat

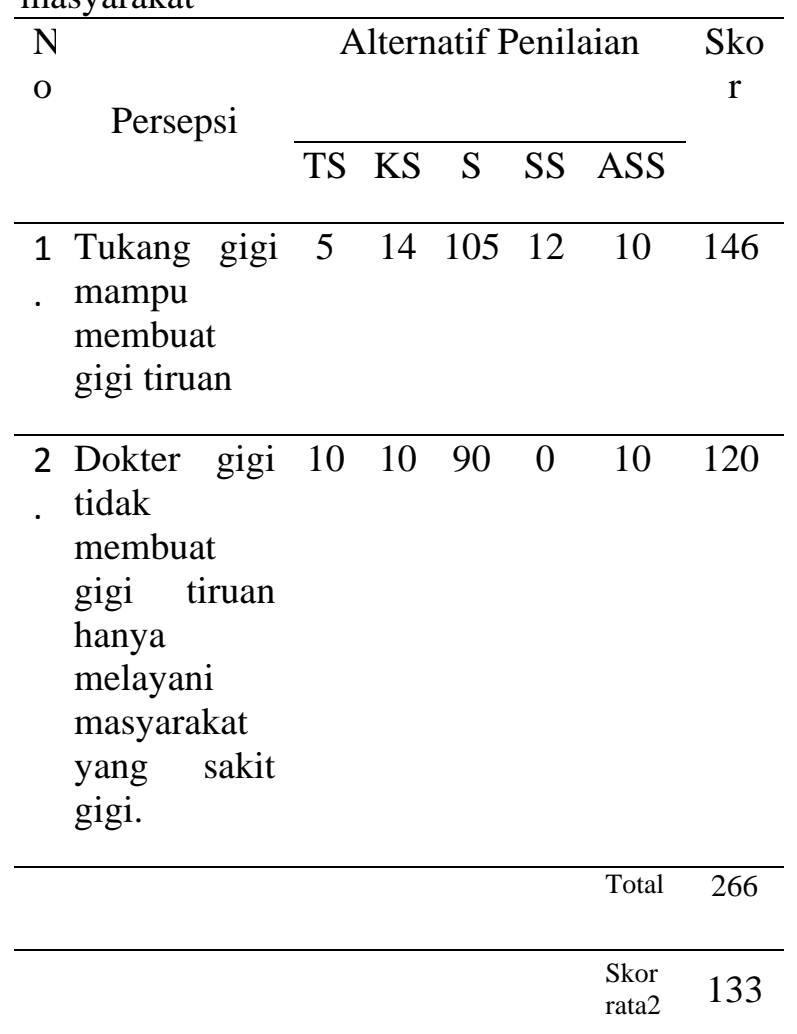

Berdasarkan skala di atas, dapat dilihat bahwa skor penilaian rata-rata faktor persepsi sebagai faktor determinan internal perilaku masyarakat tergolong dalam kategori menentukan.

Distribusi penilaian faktor motivasi sebagai faktor determinan internal perilaku masyarakat dalam pemanfaatan jasa tukang gigi dapat dilihat pada Tabel 9. 
Tabel 9.Distribusi penilaian faktor motivasi sebagai faktor internal perilaku masyarakat.

\begin{tabular}{|c|c|c|c|c|c|c|c|}
\hline $\mathrm{N}$ & \multirow[t]{2}{*}{ Motivasi } & \multicolumn{5}{|c|}{ Alternatif Penilaian } & \multirow[t]{2}{*}{ Skor } \\
\hline 0 & & $\mathrm{TS}$ & $\mathrm{KS}$ & $\mathrm{S}$ & $\begin{array}{l}\mathrm{S} \\
\mathrm{S}\end{array}$ & ASS & \\
\hline 1. & $\begin{array}{l}\text { Banyak } \\
\text { masyarakat } \\
\text { yang } \\
\text { menggunaka } \\
\text { n gigi tiruan } \\
\text { yang dibuat } \\
\text { oleh tukang } \\
\text { gigi. }\end{array}$ & 19 & 2 & 81 & 0 & 25 & 127 \\
\hline 2. & $\begin{array}{l}\text { Kebutuhan } \\
\text { untuk } \\
\text { secepatnya } \\
\text { memperbaik } \\
\text { ki } \\
\text { penampilan } \\
\text { akibat } \\
\text { kehilangan } \\
\text { gigi. }\end{array}$ & 0 & 0 & 138 & 0 & 30 & 168 \\
\hline \multirow[t]{3}{*}{3} & $\begin{array}{l}\text { Kebutuhan } \\
\text { untuk } \\
\text { secepatnya } \\
\text { memperbaik } \\
\text { i fungsi } \\
\text { penguyahan } \\
\text { yang } \\
\text { terganggu.. }\end{array}$ & 0 & 0 & 120 & 0 & 60 & 180 \\
\hline & & & & & & Total & 475 \\
\hline & & & & & & $\begin{array}{l}\text { Skor } \\
\text { rata22 }\end{array}$ & 158 \\
\hline
\end{tabular}

Berdasarkan skala di atas, dapat dilihat bahwa skor penilaian rata-rata faktor pelayanan kesehatan sebagai faktor determinan eksternal perilaku masyarakat tergolong dalam kategori menentukan.

Secara hasil keseluruhan memberikan gambaran bahwa faktor internal dengan skor penilaian rata - rata 154, masuk kategori menentukan.
Tabel 10. Distribusi penilaian faktor determinan internal perilaku masyarakat yang paling menentukan dalam pemanfaatan jasa tukang gigi

\begin{tabular}{llc}
\hline $\begin{array}{c}\mathrm{N} \\
\mathrm{o}\end{array}$ & $\begin{array}{l}\text { Faktor } \\
\text { determinan } \\
\text { internal }\end{array}$ & Skor \\
\hline 1. & Pengamatan & 173 \\
\hline 2. & Motivasi & 158 \\
\hline 3 & Persepsi & 133 \\
\hline & & 154 \\
\hline
\end{tabular}

\section{BAHASAN}

Faktor eksternal penentu determinan perilaku masyarakat dalam pemanfaatan jasa tukang gigi yaitu faktor ekonomi.

Hasil penelitian yang dilakukan menunjukkan bahwa dari dua faktor eksternal yang diteliti sebagai determinan perilaku masyarakat dalam pemanfaatan jasa tukang gigi pada pembuatan gigi tiruan lepasan, maka faktor ekonomi merupakan faktor penentu utama, dengan skor penilaian sebesar 250 masuk dalam kategori sangat menentukan. Responden sebagian besar $86,54 \%$ amat sangat setuju bahwa faktor pembiayaan yang terjangkau sebagai faktor penentu dalam pemanfaatan jasa tukang gigi.

Perawatan gigi tiruan membutuhkan biaya yang tidak sedikit. Apabila berobat ke dokter gigi akan dikenakan biaya untuk jasa pelayanan di samping biaya pembuatan gigi tiruannya, sedangkan apabila ke tukang gigi hanya dikenankan biaya pembuatan gigi tiruan. Biaya dokter gigi wajar lebih mahal dibandingkan dengan tukang gigi karena waktu dan biaya yang dikeluarkan untuk menempuh pendidikan agar memperoleh kompetensi sebagai dokter gigi tidak sedikit dan lain halnya dengan tukang gigi yang terkadang ketrampilannya hanya diperoleh secara turun temurun atau pendidikan ketrampilan sebagai tekniker gigi yang 
seharusnya digunakan dalam laboratorium dan bukan untuk berhadapan langsung dengan masyarakat.

Data kondisi sosial ekonomi masyarakat Treman Kecamatan Kauditan Kabupaten Minahasa Utara menunjukkan bahwa sebagian besar bermatapencarian atau bekerja sebagai petani, pedagang kecil-kecilan. Oleh karena itu bisa dimaklumi apabila masyarakat mencari pelayanan kesehatan yang lebih murah. Penelitian yang dilakukan oleh Teo'Filo dan Leles menyatakan bahwa 88,8\% dari sampel yang diteliti memiliki kendala keuangan yang paling banyak untuk tidak melakukan perawatan gigi tiruan. ${ }^{15}$

Hasil yang sama juga didapatkan oleh McGrath dan Bedi yang menyatakan bahwa status ekonomi merupakan prediktor yang paling penting bagi seseorang dalam mengambil keputusan untuk melakukan perawatan. Keadaan sosial-ekonomi suatu keluarga dapat diukur berdasarkan pendapatan keluarga dari hasil pekerjaan yang ada. ${ }^{16}$ Penelitian yang dilakukan oleh Sarnizia pada tahun 2008 di Medan menemukan sebanyak 92,5\% menyatakan biaya relatif lebih murah pada tukang gigi menjadi alasan utama dalam pemanfaatan jasa tukang gigi dibandingkan dengan pelayanan kesehatan gigi lainnya. ${ }^{17}$

\section{Faktor pelayanan kesehatan}

Faktor eksternal lainnya yakni faktor pelayanan kesehatan memperoleh skor penilaian sebesar 180 dan masuk kategori menentukan. Hasil penilaian terhadap faktor pelayanan kesehatan menunjukkan bahwa 82,69 amat sangat setuju bahwa faktor minimnya tenaga dokter gigi yang ada di Minahasa Utara baik yang bertugas di instansi pemerintah maupun praktek pribadi antara lain menjadi alasan sehingga masyarakat lebih memilih memanfaatkan jasa tukang gigi dalam perawatan pembuatan gigi tiruan.

Keberadaan tenaga dokter gigi yang sangat minim sangat dirasakan di daerah. Saat ini jumlah dokter gigi Indonesia berdasarkan data Persatuan Dokter Gigi Indonesia (PDGI) kira - kira 25.218 dokter gigi dan persentase terbesar berada di kota - kota besar di pulau Jawa, yakni 5.609 dokter gigi. ${ }^{18}$ Ratio dokter gigi dengan jumlah penduduk 1: 25.000. Jumlah ini masih jauh dari ratio ideal menurut WHO, yaitu $1: 10.000$. Kurangnya tenaga dokter gigi serta penyebarannya yang tidak merata antara lain menjadi salah satu kendala pemerintah dalam menangani berbagai permasalahan di bidang kesehatan gigi, termasuk dalam pembuatan gigi tiruan.

Kondisi ini memberikan peluang kepada para tukang gigi untuk melakukan praktek pembuatan gigi tiruan.Hal ini dibuktikan dengan adanya ijin yang diberikan oleh pemerintah untuk tukang gigi melakukan praktek. Ketiadaan atau minimnya dokter gigi di suatu daerah dimanfaatkan oleh para tukang gigi dengan baik, bahkan saat ini banyak ditemukan praktek tukang gigi 'door to door' atau praktek keliling menggunakan kendaraan. Di Minahasa Utara saat ini jumlah dokter gigi yang bertugas hanya 4 (empat) dokter gigi dan di kecamatan Kauditan terdapat 1 (satu) dokter gigi yang bertugas di puskesmas namun praktek pribadinya bukan di desa Treman. Hal ini juga antara lain menjadi alasan sehingga masyarakat lebih memilih perawatan di tukang gigi.

\section{Faktor internal penentu yaitu pengamatan}

Hasil penelitian tentang faktor internal lainnya sebagai determinan, menunjukkan bahwa faktor pengamatan sebagai determinan memperoleh skor penilaian sebesar 173 masuk kategori menentukan. Pada faktor pengamatan ternyata 69,23\% responden setuju bahwa pembuatan gigi tiruan di tukang gigi lebih cepat dibandingkan dengan di dokter gigi. Hal ini menunjukkan bahwa responden kurang mementingkan waktu yang dibutuhkan untuk perawatan dibandingkan biaya perawatan, ketersediaan dokter gigi, penggantian fungsi yang hilang serta 
kemampuan membuat gigi tiruan.Namun dari hasil yang diperoleh pada penelitian faktor pengamatan sebagai determinan internal perilaku masyarakat menggambarkan bahwa faktor waktu yang memengaruhi masyarakat sehingga memanfaatkan jasa tukang gigi.

Prosedur perawatan yang dilakukan oleh tukang gigi sangat berbeda dengan prosudur yang dilakukan oleh dokter gigi yang harus bolak-balik untuk melakukan perawatan gigi tiruan. Penelitian yang diperoleh Teguh pada tahun 2012 di pulau Kondingareng Makassar menunjukkan bahwa tukang gigi bekerja dengan cepat sehingga pasien tidak menunggu lama, karena rata-rata pasien hanya dicetak dan dipasangkan gigi tiruan. ${ }^{20}$

\section{Faktor motivasi}

Berdasarkan hasil penelitian yang ada, diperoleh hasil bahwa dari ketiga faktor internal yang diteliti faktor motivasi menduduki urutan terakhir sebagai faktor penentu determinan perilaku masyarakat dimana skor penilaian sebesar 154 masuk kategori menentukan.Pencapaian skor penilaian ini paling rendah dibandingkan kedua faktor internal pendahulu.Penulis berpendapat bahwa kebutuhan untuk memperbaiki fungsi kurang menjadi faktor penentu karena kehilangan gigi mungkin jumlahnya tidak terlalu banyak dan letaknya tidak memengaruhi penampilan, sehingga fungsi pengunyahan tidak terlalu terganggu, demikian halnya dengan fungsi bicara dan estetik.

Pada penelitian yang dilakukan diperoleh hasil 88,46\% responden setuju bahwa kebutuhan untuk secepatnya memperbaiki penampilan akibat kehilangan gigi merupakan sumber motivasi utama masyarakat menggunakan jasa tukang gigi, mungkin disebabkan karena responden terbesar adalah perempuan (61,34\%). Kondisi ini dapat menjadi alasan pendorong bagi masyarakat untuk sesegera mungkin menggantikan gigi yang hilang. Secara umum perempuan lebih memper- hatikan segi penampilan dibandingkan laki-laki.

\section{Faktor persepsi}

Hasil penelitian selanjutnya faktor persepsi dengan skor penilaian 133, penentu sehingga masyarakat lebih memilih memanfaatkan jasa tukang gigi dalam pembuatan gigi tiruan. Pandangan masyarakat terbesar $(67,31 \%)$ menunjukkan bahwa tukang gigi memiliki kemampuan dalam pembuatan gigi tiruan. Pandangan ini mungkin terbentuk berdasarkan pengalaman masyarakat yang diperoleh dari keluarga atau kerabat dekat atau pengalaman yang dialami sendiri oleh masyarakat yang kemudian membentuk persepsi masyarakat.

Persepsi juga bisa terbentuk dari imej masyarakat bahwa dokter gigi hanya bertugas untuk menyembuhkan penyakit atau keluhan sakit.Tidak dipungkiri bahwa keberadaan tukang gigi sejak jaman dahulu kala bekerja untuk melayani pembuatan gigi tiruan ikut memengaruhi persepsi masyarakat. Hasil yang diperoleh dalam penelitian ini sejalan dengan penelitian yang telah dilakukan oleh Ayu Angraeni mengenai persepsi masyarakat bahwa tukang gigi mampu membuat gigi tiruan sebesar $74,76 \%{ }^{19}$

Hasil secara keseluruhan memberikan gamabaran bahwa faktor eksternal dengan skor penilaian rata - rata 215 , tergolong kategori sangat menentukan merupakan determinan yang lebih menentukan daripada faktor internal dengan skor penilaian rata - rata 154 masuk kategori menentukan.

\section{SIMPULAN}

1. Determinan perilaku masyarakat yang paling menentukan dalam pemanfaatan jasa tukang gigi, yakni determinan yang berasal dari luar masyarakat (faktor eksternal).

2. Faktor biaya perawatan yang tergolong dalam faktor ekonomi, merupakan determinan perilaku 
masyarakat eksternal yang paling menentukan.

\section{SARAN}

1. Adanya upaya yang nyata dari pemerintah dalam penyediaan tenaga dokter gigi serta pelayanan kesehatan yang bermutu dan terjangkau

2. Diadakan penelitian lebih lanjut, untuk memperoleh gambaran determinan perilaku masyarakat dalam pemanfaatan jasa tukang gigi yang berada di Kabupaten Minahasa utara.

\section{DAFTAR PUSTAKA}

1. Petersen PE, Kandelman D, Arpin S, Ogawa H. Global oral health of older people-call for public health action. Community Dent Health. 2010;27(4):257-67.

2. Gunadi, Haryanto et al. Buku Ajar Ilmu Geligi Tiruan Sebagian Lepasan. Jakarta: Hipokrates, 1991.

3. World Health Organization. Oral Health Available from: http://www.who.int/mediacentre/fa ctsheets/fs318/en/index.html

4. Depertemen Kesehatan Republik Indonesia. Laporan Riset Kesehatan Dasar Nasional 2007. Jakarta: Badan Penelitian dan Pengembangan Kesehatan. Available from: http://www.docstoc.com/docs/1970 7850/Laporan-Hasil-RisetKesehatan-Dasar-(RISKESDAS)Nasional-2007

5. Notoatmodjo M. Pengantar Pendidikan Kesehatan dan Ilmu Perilaku. Jakarta: PT Rineka Cipta, 2003.

6. Notoatmodjo M. Promosi Kesehatan. Jakarta: PT Rineka Cipta, 2010.

7. Dinas Kesehatan Minahasa Utara. Data Dokter Gigi, yang Bertugas di Rumah Sakit dan Puskesmas Kabupaten Minahasa Utara, 2013.
8. Aplikasi Valplast pada gigi tiruan sebagian lepasan. [serial online] [cited 2013 Mei 7]. Available from:

URL:http://id.scribd.com/doc/ 118623054/Aplikasi-Valplastpada-gigi-tiruan-sebagian

9. Tamin HZ. Peningkatan mutu pelayanan prostondontik dan inovasi pelaksanaan tridharma perguruan tinggi. Medan: USU. 2007; p.10-11

10. Peraturan Menteri Kesehatan Nomor 339/Menkes/Per/V/1989. Pekerjaan Tukang Gigi. Jakarta

11. Kemenkes Stop Izin Baru Tukang Gigi - Jurnal Nasional - Senin, 19 Mar 2012 halaman 9. Available from: http://www. jurnas.com/halaman/9/2012-03$19 / 202870$ tukang gigi

12. http://fk.uns.ac.id/static/materi/eko nomi_kesehatan_Prof_Bhisma_Murti.pdf

13. Nasir ABD. Metodologi Penelitian Kesehatan. Jakarta: Nuha Medika, 2010.

14. Dinas Kesehatan Sulawesi Utara. Data dokter gigi yang bertugas di rumah sakit dan puskesmas Sulawesi Utara, 2013

15. Teo'filo LT, Leles CR. Patient' self-perceived impacts and prostodontic need at the time and after tooth loss. Braz Dent Journal. 2007;18(2):91-6.

16. McGrath C, Bedi R. Severe tooth loss among UK adults - who goes for oral rehabilitation? J Oral Rehabil. 2002;29:240-4.

17. Meutuah S. Hubungan karakteristik pengguna gigi palsu dengan pemanfaatan jasa tukang gigi di kota Medan tahun 2008. Usu repository [serial online] 2008 [cited 3013 juli 13]. Available from

http://repository.usu.ac.id/bitstream 1123456789/14734/1/090E00980.p $\underline{\mathrm{df}}$ 
18. Fenn HRB, Gimson AP, Liddelow KP. Clinical Dental Prosthetics. Second Edition, 1961

19. Abidin T. Buku panduan pelaksanaan kegiatan di Desa Binaan Pepsodent FKG USU. Medan: Usu Press, 2009.

20. Ayu A. Persepsi masyarakat terhadap pembuatan gigi tiruan. Jurnal volume 1:desember. P 2-3

21. Putra T. Tingkat kepuasan masyarakat pulau Kodingareng terhadap pelayanan gigi dan mulut.
Unhas repository [serial online] 2012 [cited 2013 juli 13]. Available

from:http://repository.unhas.ac.id/h andle/123456789/1039 